\title{
Eksplorasi benih Jati Putih (Gmelina arborea Roxb) dari berbagai variasi habitat untuk populasi pemuliaan
}

\author{
Exploration of White Teak seeds (Gmelina arborea Roxb) from various habitat variations \\ for breeding populations
}

\author{
Dedi Setiadi ${ }^{1}$ dan Hamdan Adma Adinugraha ${ }^{1}$ \\ ${ }^{I}$ Balai Besar Penelitian Bioteknologi dan Pemuliaan Tanaman Hutan \\ Jl. Palagan Tentara Pelajar Km. 15, Purwobinangun, Pakem, Sleman, Yogyakarta 55582, Indonesia
}

\begin{abstract}
ABSTRAK
Jati putih (Gmelina arborea Roxb) merupakan salah satu jenis yang dikembangkan untuk pembangunan hutan tanaman, jenis ini merupakan pohon eksotik yang pertumbuhannya cepat, teknik penanamannya tidak sulit dan mempunyai nilai ekonomi yang cukup baik. Kayunya dipakai untuk berbagai keperluan khususnya untuk pembuatan bahan kontruksi, pertukangan, kayu lapis, korek api, peti kemas dan bahan kerajinan kayu lainnya. Salah satu aspek yang menentukan keberhasilan pembangunan hutan tanaman adalah tersedianya benih terutama benih bermutu yaitu unggul secara genetik, fisik dan fisiologis, tersedia dalam jumlah yang cukup, tepat waktu dan memiliki kemampuan beradaptasi dengan lingkungan tempat tumbuhnya. Pengembangan tanaman ini perlu dibarengi dengan program pemuliaan, salah satu kegiatan pemuliaan tanaman hutan adalah eksplorasi. Kegiatan eksplorasi suatu jenis tanaman pada habitat alamnya penting dilakukan untuk menunjang kegiatan penelitian dan pengembangan suatu institusi maupun untuk memenuhi kebutuhan pasar akan benih tersebut. Tujuan dari eksplorasi benih adalah untuk mendapatkan benih Jati putih yang mewakili berbagai variasi habitat untuk mendukung kegiatan pemuliaan. Eksplorasi benih Jati putih dilakukan di Kalianda (Lampung Selatan), Bondowoso (Jawa Timur), Bantul (Yogyakarta), Parung panjang (Jawa Barat) dan Lombok (Nusa Tenggara Barat). Hasil ekplorasi diperoleh sebanyak 108 pohon induk dari Kalianda 25 pohon induk dengan ukuran benih $(18,32 \mathrm{~mm} ; 10,25 \mathrm{~mm})$, Bondowoso 30 pohon induk $(17,78 \mathrm{~mm}$; $9,64 \mathrm{~mm})$, Bantul 21 pohon induk (19,24 mm; 11,40 mm), Parung panjang 15 pohon induk (19,41 mm; 9,42 mm) dan Lombok 17 pohon induk $(18,58 \mathrm{~mm} ; 10,31 \mathrm{~mm})$.
\end{abstract}

Kata kunci : Eksplorasi, Gmelina arborea, ukuran benih, progam pemuliaan

\begin{abstract}
White teak (Gmelina arborea Roxb) is one of the types developed for the development of plantations, this species is an exotic tree that grows quickly, the planting technique is not difficult and has a good economic value. The wood is used for various purposes, especially for the manufacture of construction materials, carpentry, plywood, matches, containers and other wood craft materials. One aspect that determines the success of plantation development is the availability of seeds, especially quality seeds that are superior genetically, physically and physiologically, available in sufficient quantities, on time and have the ability to adapt to the environment in which they grow. The development of this plant needs to be accompanied by a breeding program, one of the forest plant breeding activities is exploration. Exploration activities of a type of plant in its natural habitat are important to support research and development activities of an institution and to meet market needs for these seeds. The purpose of seed exploration is to get white Teak seeds that represent a variety of habitats to support breeding activities. Exploration of white teak seeds is carried out in Kalianda (South Lampung), Bondowoso (East Java), Bantul (Yogyakarta), Parung Panjang (West Java) and Lombok (West Nusa Tenggara). The results of the exploration obtained 108 mother trees from Kalianda 25 mother trees with seed size $(18.32 \mathrm{~mm} ; 10.25 \mathrm{~mm})$, Bondowoso 30 mother trees $(17.78 \mathrm{~mm}$; $9.64 \mathrm{~mm})$, Bantul $21 \mathrm{mother}$ trees $(19,24 \mathrm{~mm} ; 11.40 \mathrm{~mm})$, Parung length 15 mother trees $(19.41 \mathrm{~mm} ; 9.42 \mathrm{~mm})$ and Lombok 17 mother trees $(18.58 \mathrm{~mm}$; 10,31 $\mathrm{mm})$.
\end{abstract}

Keywords: Exploration, Gmelina arborea, seed size, breeding program

\footnotetext{
* Penulis korespondensi:

E-mail: setiadi2009@yahoo.com
} 


\section{Pendahuluan}

Pembangunan Hutan Tanaman Industri merupakan kegiatan yang harus dilakukan untuk mengantisipasi akan kebutuhan dan kecukupan sumber bahan mentah bagi industri kayu. Sebaliknya, kayu akan semakin langka seiring dengan semakin menurunnya kuantitas dan kualitas hutan, sehingga keberadaan hutan rakyat sebagai salah satu pemasok kayu menjadi penting keberadaannya (Diniyati \& Awang, 2010). Pembangunan hutan tanaman dapat dijadikan salah satu sarana untuk mengurangi tekanan terhadap keberadaan hutan produksi alam yang mengandung jenis-jenis tanaman pohon berharga sehingga perlu dijaga kelestariannya. Salah satu jenis tanaman yang potensial untuk dikembangkan pada hutan tanaman, khususnya hutan rakyat adalah Jati putih (Gmelina arborea Roxb). Jenis ini merupakan jenis pohon eksotik yang pertumbuhannya cepat, teknik penanamannya tidak sulit dan mempunyai nilai ekonomi yang baik. Kegunaan kayu Jati putih adalah sebagai bahan pembuatan papan partikel, core kayu lapis, korek api, peti kemas, dan bahan kerajinan kayu (Falah, dkk. 2005).

Para pelaksana hutan tanaman industri yang mengembangkan Jati putih, sebagian besar menggunakan benih yang berasal dari sumber benih yang belum teruji keunggulannya pada areal jenis tersebut yang akan dikembangkan, sehingga akan berakibat rendahnya produktivitas kayu yang dihasilkan. Salah satu aspek yang menentukan keberhasilan pembangunan hutan tanaman adalah tersedianya benih terutama benih bermutu. Salah satu kriteria benih bermutu yang dapat diukur adalah persen kecambah benih, keserempakan tumbuh dan kecepatan berkecambah. Hal ini dipengaruhi oleh ukuran benih dan hal ini erat kaitannya dengan cadangan makanan yang terdapat dalam benih terutama karbohidrat, protein dan lemak (Soetopo, 2005).

Seiring dengan laju degradasi hutan yang sudah sangat memprihatinkan, maka kegiatan konservasi untuk upaya penyelamatan maupun mendukung program pemuliaan jenis Jati putih menjadi hal yang sangat mendesak untuk dilakukan. Kegiatan awal dari program konservasi sumber daya genetik dan pembangunan populasi pemuliaan adalah ekplorasi dan pengumpulan benih (Hakim, dkk, 2010). Langkah awal yang harus dilakukan untuk menentukan jenis, sumber asal benih dan pohon induk yang unggul dengan populasi dasar yang tidak sempit adalah dengan melakukan eksplorasi benih dari jenis yang akan dikembangkan dari berbagai populasi alamnya. Tujuan dari eksplorasi benih adalah untuk mendapatkan benih jenis ini yang mewakili berbagai variasi habitat untuk mendukung kegiatan pemuliaan melalui uji provenan atau uji genetik lainnya.

\section{Metodologi}

\section{Bahan Penelitian}

Bahan dan perlengkapan yang diperlukan dalam penelitian ini adalah sebagai berikut; perlengkapan lapangan berupa cumping unit dan peralatan penelitian, seperti GPS (Global Position System) pH meter, kompas, teropong (binocular), haga meter, phiband, kaliper, parang, pisau, ketapel, kamera, gunting, staples dan tallysheet. Bahan pengambilan sampel benih, berupa alat tulis, kantong terigu, kantong benih, label benih, dan penyaring benih/pengayak benih.

\section{Waktu dan tempat}

Kegiatan ekplorasi dan pengumpulan benih Jati putih dilakukan mulai pertengahan bulan Mei 2015 di beberapa habitat tempat tumbuh Jati putih yaitu di Kalianda (Lampung Selatan), Bondowoso (Jawa Timur), Bantul (Yogyakarta), Parung panjang (Jawa Barat) dan Lombok (Nusa Tenggara Barat) Setiadi (2016).

\section{Studi pustaka dan kontak person}

Studi pustaka dilakukan, selain untuk mengetahui sebaran alam dan musim buah masak juga untuk mengetahui teknik pembibitan dan teknik silvikultur dari jenis target, sedangkan kontak person diperlukan untuk mengetahui kepastian keberadaan jenis target dan waktu yang tepat untuk pelaksanaan eksplorasi, alat transportasi dan aksesibilitas menuju lokasi penelitian (Setiadi \& Hamdan, 2015).

\section{Survey dan pendataan pohon induk}

Berdasarkan informasi dari kontak person dan dinas terkait setempat tentang pohon target yang akan dieksplorasi maka dilakukan eksplorasi pohon-pohon induk dan pendataan karakteristik pohon meliputi diameter batang, tinggi bebas cabang, tinggi total, diameter tajuk, kelimpahan biji, serta kondisi lingkungan dari tegakan hutan seperti frekwensi pohon, asosiasi jenis pohon dengan pohon lain, posisi koordinat pohon, ketinggian tempat dengan tallysheet. Berdasarkan pedoman Penyelenggaraan Konservasi Sumber Daya Genetik untuk Jenis Tanaman Hutan, secara umum untuk menentukan jumlah pohon pada setiap populasi minimal dari 20 pohon induk yang terdistribusi 
secara merata di populasi tersebut (Rimbawanto, dkk. 2008). Jarak antar pohon \pm 100 meter yang diasumsikan tidak terjadi perkawinan antar pohon induk yang dikoleksi buahnya.

\section{Pengumpulan, pengemasan dan penanganan benih}

Biasanya buah yang sudah masak fisiologis atau tua ditandai dengan warna kulitnya sudah kecoklat-coklatan. Kegiatan pengumpulan buah dilakukan bersamaan dengan kegiatan survey dan pendataan pohon induk. Jika buah sudah masak dan pohon dapat dipanjat, maka dapat dilakukan pengumpulan buah dengan cara memanjat atau menjatuhkan buah dengan alat galah atau ketapel, buah dikumpulkan dan diberi label dari setiap individu pohon serta dimasukan dalam kantong benih.

Kegiatan penanganan dan pengemasan buah harus dilakukan secepatnya setelah pengumpulan dilakukan di lapangan (Schmidt, 2000). Kelembabannya harus dijaga, sebelum buah dimasukan pada kardus atau karung, buah tersebut dimasukan dulu pada kantong plastik dan disemprotkan air kemudian ditutup rapat di staples dan dilakban untuk menjaga kelembaban, hal ini dilakukan agar buah tidak kering dan mati. Kegiatan ekstraksi benih diantaranya buah yang sudah masak tersebut langsung dibelah pakai pisau dan lansung diambil bijinya kemudian dijemur sampai kering, ada pula cara lain yaitu buah yang ada didalam karung dimasukan kedalam air dan diinjak-injak sampai bijinya keluar dari daging buahnya (Setiadi, 2016). Selanjutnya pelabelan hasil koleksi (seedlot) dibuat untuk identifikasi lokasi dan nomor individu pohon yang dikoleksi benihnya. Pelabelan tersebut meliputi: nomor seedlot, yang dibuat untuk menunjukkan nomor urut lokasi dimana eksplorasi benih dilakukan. Selanjutnya penyimpanan benih, dengan memasukan benih kedalam kantong atau stoples plastik yang telah diberi label dan disusun di rak-rak ruangan yang dingin Dry Cold Storage (DCS) yang telah disesuaikan suhunya.

\section{Pengukuran benih}

Benih yang terkumpul dan terseleksi hasil ekplorasi dari berbagai variasi habitat tersebut kemudian dilakukan pengukuran benih tebal dan diameternya dengan menggunakan kaliper. Seperti yang dilaporkan Siregar (2010) pengukuran benih tersebut dikelompokan menjadi tiga ukuran benih yaitu untuk ukuran diameter $(\mathrm{mm})$ besar ( 10 13), sedang (7-10), kecil $(<10)$ dan ukuran tebal $(\mathrm{mm})$ yaitu besar (16-22), sedang (14-19), kecil (14-16). Sedangkan untuk media tumbuhnya yang terbaik yaitu dengan menggunakan arang aktif tempurung kemiri sebagai komponen media tumbuh dengan kadar 15\% + tanah 75\% dan pupuk kandang 10\% (Lempang dan Tikupadang, 2013). Selanjutnya gambaran secara ringkas kegiatan eksplorasi benih G. arborea disajikan pada Gambar 1.
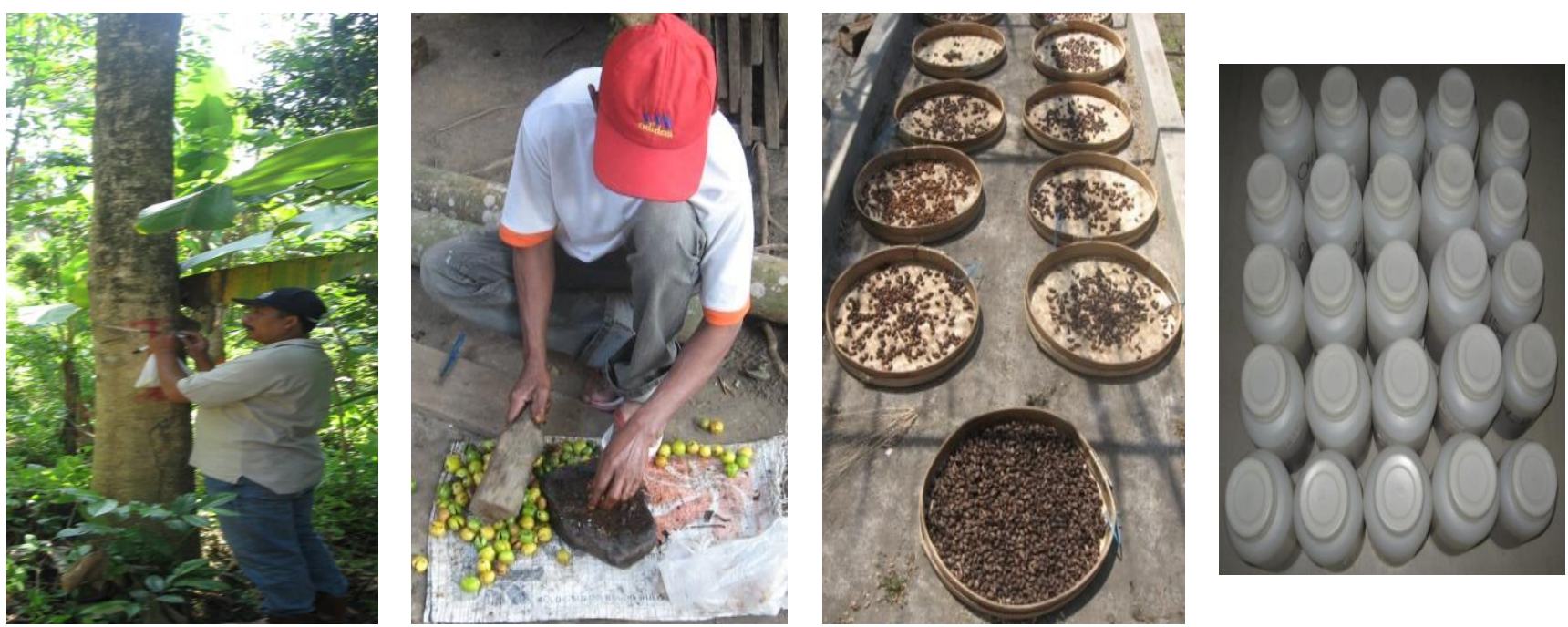

Gambar 1. Pendataan pohon induk, gmelina (Gmelina arborea Roxb) penanganan benih berupa pengupasan dengan cara dipukul, dikupas pakai pisau, penjemuran dan penyimpanan benih dilemari pendingin (Setiadi, 2016) 


\section{Hasil dan pembahasan}

\section{Aksesibilitas dan Kondisi Wilayah}

\section{a. Kalianda (Lampung Selatan)}

Pengambilan benih di Lampung tepatnya di desa Sripendowo, kecamatan Ketapang, kabupaten Lampung Selatan. Perjalanan ke lokasi tersebut bisa ditempuh dengan jalan darat lebih kurang 1,5 jam dari kota kabupaten. Dari hasil wawancara dengan petugas penyuluh setempat, lokasi pengambilan sumber benih tersebut merupakan bekas areal PT. DARMALA (INHUTANI. III) dengan jenis tanaman didominasi jenis Jati putih. Pada masa terjadinya reformasi terjadi penyerobotan lahan dan penebangan/penjarahan yang dilakukan oleh masyarakat. Dari sisa-sisa tegakan yang ada, masyarakat yang peduli terhadap kelangsungan tegakan pohon Jati putih, masyarakat mengumpulkan benihnya dan ditanam di lahan/kebun miliknya. Tanaman tersebut sekarang sudah berumur lebih kurang 7 tahun dan sudah mendapat sertifikasi dari intasi perbenihan dengan kelas sumber benih Tegakan Benih Teridentifikasi sejak tahun 2013. Hasil kegiatan eksplorasi benih di Kalianda (Lampung Selatan) sebanyak 25 pohon induk.

\section{b. Bondowoso (Jawa Timur)}

Pengambilan benih Jati putih dilakukan di empat kecamatan yaitu; Sumberwringin, Sukosari, Mangli dan Prajekan. Di kecamatan Sumberwringin tegakan tersebut ditemukan pada areal hutan rakyat yang tersusun dalam tegakan campuran di desa Sukerejo, Sumberwringin dan Rejoagung. Hasil kegiatan eksplorasi benih di Bondowoso (Jawa Timur) sebanyak 30 pohon induk. Keadaan tegakan Jati putih yang berada didekat pekarangan rumah-rumah penduduk keberadaan pohonnya tidak terlalu tinggi karena dimanfaatkan untuk pakan ternak dengan cara dipangkas ranting dan daunnya. Di kecamatan Sukosari tumbuh dan tersebar di desa Sukosari, Ketapang dan Nogosari. Tanaman ini tumbuh pada areal hutan rakyat dan tegalan pematang-pematang tanaman tebu yang sewaktu-waktu ranting daunnya dipangkas sebagai pakan ternak tambahan terutama dimusim kemarau dimana masyarakatnya kebanyakan memelihara ternak kambing dan sapi. Di kecamatan Mangli tanaman ini tumbuh dan menyebar di areal hutan rakyat dan sebagai tanaman peneduh dipinggir-pinggir jalan. Di Kecamatan Prajekan yang itu di desa Walidono, tanaman Jati putih sudah ditanam secara teratur dengan jarak tanam $5 \mathrm{~m}$ x $5 \mathrm{~m}$, umur kurang lebih 10 tahun dengan luasan sekitar 1 ha dan telah ditetapkan oleh BPTH sebagai tegakan benih teridentifikasi (Setiadi \& Hamdan, 2015).

\section{c. Bantul (Yogyakarta)}

Pengambilan benih Jati putih dilakukan di empat kecamatan yaitu; Dlingo, Imogiri, Pajang dan Playen (Gunung Kidul). Hasil kegiatan eksplorasi benih di empat kecamatan di Bantul (Yogyakarta) sebanyak 21 pohon induk. Keadaan tegakan Jati putih ditemukan pada areal hutan rakyat yang tersusun dalam tegakan campuran dan lahanlahan tegalan yang berumur antara 10-15 tahun. Di kabupaten Bantul masak buah hampir seragam yaitu di bulan Nopember sampai Desember.

\section{d. Parungpanjang (Bogor, Jawa Barat)}

Pengambilan benih Jati putih dilakukan pada plot uji Hutan Penelitian Parungpanjang (Balai Penelitian Teknologi Perbenihan Tanaman Hutan Bogor) yang dibangun pada tahun 1992. Secara administratif Hutan Penelitian Parungpanjang berada di desa Gintung Cilejet dan Jagabaya, kecamatan Parungpanjang, kabupaten Bogor, propinsi Jawa Barat. Berdasarkan administrasi kehutanan, lokasi berada di Resort Polisi Hutan (RPH) Jagabaya, Bagian Kesatuan Pemangkuan Hutan (BKPH) Parung Panjang, Kesatuan Pemangkuan Hutan (KPH) Bogor (Statistik Dalam Angka, 2017). Perjalanan kelokasi pengambilan benih Jati putih bisa dilakukan jalan darat dengan kendaraan umum dan buah masak secara pisiologis pada bulan Oktober sampai November.

\section{e. Lombok (Nusa Tenggara Barat)}

Pengambilan benih Jati putih (Gmelina arborea) di Nusa Tenggara Barat (NTB) tepatnya di Lombok Barat dari 4 kecamatan (Sesaot, Lembar, Narmada dan Kekalik), sedangkan dari Lombok Tengah dari 2 kecamatan (Pringgarat dan Kopang). Pengambilan benih tersebut satu lokasi dari kebun benih teridentifikasi yang sudah bersertifikat dari BPTH Bali Nusra di kecamatan Lembar dan yang lainnya dari hutan rakyat yang rata-rata berumur 12-15 tahun. 
Dari hasil ekplorasi yang telah dilakukan pada beberapa lokasi, waktu puncak musim buah, yaitu buah sudah masak fisiologis dalam jumlah banyak dari benih Jati putih pada masing-masing lokasi tidak serempak, oleh karena itu untuk kegiatan di masa yang akan datang, diperlukan informasi yang akurat dari kontak person di lapangan, tetapi kebanyakan buah masak fisiologis Jati putih sekitar bulan Agustus sampai bulan Oktober. Tegakan benih yang terpilih (pohon plus) tegakan benih tersebut kemudian dikasih tanda/label dan dicatat letak koordinatnya. Kegiatan selanjutnya yaitu pengunduhan benih dengan cara dipanjat, benih yang terkumpul dari masing-masing pohon/individu kemudian dikasih nomor/label dan diekstraksi. Hasil kegiatan eksplorasi benih di Lombok (Nusa Tenggara Barat) sebanyak 17 pohon induk.

\section{Ekplorasi}

Tanaman Jati putih merupakan jenis yang banyak dikembangkan di hutan rakyat dan disukai petani karena cepat tumbuh dan mudah budidayannya (Anggraeni \& Mindawati, 2011). Dimana kebutuhan benih untuk hutan rakyat sebenarnya sangat besar, namun luasan hutan ini terfragmentasi dalam luasan-luasan kecil, terutama di Jawa, dan jumlah pengelola yang terlibatpun sangat besar. Dengan demkian, jika hanya bertumpu pada peran instansi pemerintah, yang tidak memiliki cukup dana dan sumberdaya manusia yang mampu melayani seluruh kebutuhan dan permasalahan yang ada, upaya penyadaran terhadap penggunaan benih berkualitas dan upaya pembangunan sumber benih untuk memenuhi kebutuhan tidaklah mungkin terselesaikan. Dengan kondisi seperti ini perlu keterlibatan masyarakat dalam upaya peningkatan kualitas hutan rakyat yang berbasis benih bermutu. Dimana salah satu kriteria benih bermutu yang dapat diukur adalah persen kecambah benih, keserempakan tumbuh dan kecepatan berkecambah (Haryadi, dkk. 2006). Namun dalam mendapatkan benih yang bermutu harus memperhatikan asal-usul pohon induknya secara jelas. Masak fisiologis buah Jati putih masing-masing habitat berbeda, di mulai dari bulan Juli sampai dengan Desember, tetapi secara keseluruhan masa panen raya pada bulan Oktober dan November. Seperti pada kantong-kantong wilayah sebaran Jati putih di Jawa dan Nusa Tenggara Barat (Parungpanjang, Bantul, Bondowoso dan Lombok), sedangkan masak fisiologis buah Jati putih di wilayah Lampung kebanyakan sekitar bulan Juli. Maka pada bulan-bulan tersebut dilakukan eksplorasi pengambilan materi genetik buah Jati putih yang akan digunakan untuk uji provenan dan uji genetik lainnya. Perbedaan masak fisiologis juga terjadi pada jenis lainnya seperti Mindi (Melia azedarach) yang dilaporkan Pamoengkas, dkk. (2012), dimana setiap sekuen perkembangan berbeda untuk setiap lokasi dimana tanaman Mindi tumbuh. Pohon Jati putih berukuran sedang dengan tinggi dapat mencapai 30-40 m, berbatang silindris dengan diameter rata-rata $60 \mathrm{~cm}$, kadang-kadang dijumpai pohon yang berdiameter $140 \mathrm{~cm}$ di hutan alam. Kulit halus atau bersisik dengan warna cokelat muda atau abu-abu, ranting halus licin dan bebulu halus, warna bunga kuning terang mengelompok dalam tandan besar (30-350 bunga pertandan) bunga sempurna dengan panjangnya lebih $2,5 \mathrm{~cm}$ berbentuk tabung dengan lima helai mahkota. Daun bersilang, bergerigi atau bercuping, berbentuk jantung berukuran $10-25 \mathrm{~cm}$ x $5-18 \mathrm{~cm}$. Jati putih setelah berumur 5 tahun mulai berbunga. Buahnya berdaging dengan panjang 2-3,5 cm, kulit mengkilap, mesokorp lunak agak manis. Bijinya keras seperti batu, panjangnya 1,6-2,5 cm dengan permukaan licin, satu ujung bulat dan ujung lainnya meruncing, jika dipotong melintang, biji terdiri dari 4 ruang dan sedikitnya dalam satu ruang berisi benih. Ukuran benih 6-9 mm sesuai dengan ukuran biji, berat biji batu atau $1 \mathrm{~kg}$ biji batu ada 700-1200 biji (Syaffari \& Danu. 2013). Hasil eksplorasi dan pengumpulan pada habitat tempat tumbuh Jati putih yaitu di Kalianda (Lampung Selatan), Bondowoso (Jawa Timur), Bantul (Yogyakarta), Parung panjang (Jawa Barat) dan Lombok (Nusa Tenggara Barat) disajikan pada Tabel 1. 
Tabel 1. Hasil ekplorasi dan pengumpulan benih Jati putih (Gmelina arborea Roxb) dari Kalianda, Bantul, Parungpanjang, Bondowoso dan Lombok

\begin{tabular}{|c|c|c|c|c|c|c|}
\hline \multirow[b]{2}{*}{ No } & \multirow{2}{*}{$\begin{array}{l}\text { Lokasi } \\
\text { Sumber Benih }\end{array}$} & \multirow{2}{*}{$\begin{array}{c}\text { Ketinggian } \\
\text { tempat } \\
(\mathrm{m} \mathrm{dpl})\end{array}$} & \multicolumn{2}{|c|}{ Koordinat } & \multirow{2}{*}{$\begin{array}{c}\text { Jumlah } \\
\text { pohon } \\
\text { induk }\end{array}$} & \multirow[t]{2}{*}{ Waktu Kegiatan } \\
\hline & & & $\mathrm{LS}$ & BT & & \\
\hline 1. & $\begin{array}{l}\text { Kalianda (Lampung } \\
\text { Selatan) }\end{array}$ & 159 & $05^{0} 44^{\prime} 64^{\prime \prime}$ & $105^{0} 44^{\prime} 35^{\prime \prime}$ & 25 & Awal Juli 2015 \\
\hline 2. & $\begin{array}{l}\text { Bondowoso (Jawa } \\
\text { Timur) }\end{array}$ & 836 & $07^{0} 59^{\prime} 80^{\prime \prime}$ & $113^{0} 49^{\prime} 17^{\prime \prime}$ & 30 & Oktober 2015 \\
\hline 3. & Bantul (Yogyakarta) & 146 & $07^{0} 56^{\prime} 13^{\prime \prime}$ & $110^{0} 27^{\prime} 34^{\prime}$ & 21 & November 2015 \\
\hline 4. & $\begin{array}{l}\text { Parungpanjang (Bogor, } \\
\text { Jawa Barat) }\end{array}$ & 52 & $06^{0} 20^{\prime} 49^{\prime \prime}$ & $106^{0} 06^{\prime} 33^{\prime \prime}$ & 15 & Oktober 2015 \\
\hline 5. & $\begin{array}{l}\text { Lombok (Nusa } \\
\text { Tenggara Barat) }\end{array}$ & 310 & $08^{0} 32^{\prime} 32^{\prime \prime}$ & $116^{0} 14^{\prime} 10^{\prime}$ & 17 & Oktober 2015 \\
\hline
\end{tabular}

Sumber: Setiadi \& Hamdan (2015)

\section{Penangan Benih Paska Eksplorasi}

Pengunduhan buah untuk tujuan uji tertentu sebaiknya pohonnya dipanjat sehingga buah tidak tercampur antar pohon dan masing-masing buah diberi label sesuai lokasi dan nomor pohon yang dipanjat. Setelah benih diunduh, selanjutnya penanganan dan pemrosesan benih, dimulai dengan pengangkutan buah ketempat pemrosesan. Di tempat pemrosesan, buah hendaknya disortasi dalam kelompok yang segera diproses (kuning dan coklat) dan kelompok yang memerlukan pemasakan pasca panen (hijau kekuningan). Pemasakan demikian dilakukan di bawah naungan dengan menebar buah setebal 10-15 cm hingga berubah warna kuning. Pengupasan daging buah dikerjakan secara manual dengan memukul buah hingga terlepas daging buahnya atau di belah pakai pisau kemudian dicuci dengan air. Sisa daging buah biasanya masih menempel dibiji setelah pengupasan, sehingga diperlukan pembersihan lanjutan yaitu dengan menggosok biji dengan pasir dicampur air sampai daging buahnya terlepas. Benih Jati putih dapat digolongkan sebagai benih ortodoks yaitu benih yang akan tetap baik bila disimpan dalam kondisi kering atau berkadar air rendah. Benih yang sudah kering dengan kadar air 5-8\% yang disimpan dalam suhu $4-5^{\circ} \mathrm{C}$ pada lemari pendingin Dry Coold Storage (DCS). dapat bertahan beberapa tahun tanpa ada penurunan daya kecambah. Untuk pencegahan terhadap perkembangan jamur dilakukan dengan mencampur fungisida berbentuk tepung pada benih sebelum proses penyimpanan (Pramono, 2008).

\section{Ukuran Benih Jati Putih}

Benih merupakan salah satu faktor penentu keberhasilan pembangunan hutan tanaman. Benih haruslah tersedia dalam jumlah yang cukup pada waktu yang tepat dengan mutu yang baik, tanpa semua itu maka keberhasilan penanaman sering mengecewakan. Salah satu kriteria benih bermutu baik dapat diukur dengan persen kecambah, keserempakan tumbuh dan kecepatan berkecambah. Kecepatan perkecambahan tersebut dipengaruhi oleh faktor genetik dan faktor lingkungan seperti tanah dan iklim mikro. Faktor genetik terutama struktur kandungan cadangan makanan yang terdapat dalam benih seperti karbohidrat, protein, lemak dan hormon pengatur tumbuh. Besarnya kandungan cadangan makanan ini dipengaruhi oleh ukuran benih, semakin besar ukuran benih maka kandungan cadangan makanan yang terdapat dalam benih semakin tinggi dan akan menentukan daya kecambah (Siregar, 2010). Benih memegang peranan penting dalam pembangunan hutan tanaman, benih yang dikumpulkan dari berbagai sumber yang berbeda akan berbeda dalam viabilitas, perkecambahan, pertumbuhan dan performabiomasa (Singh \& Batt, 2008; Sumardi, dkk. 2015). Ukuran benih ini sering bervariasi, walaupun pada jenis tanaman yang sama. Seperti yang ditunjukkan pada Tabel 2 dari hasil eksplorasi benih Jati putih dari beberapa habitat tempat tumbuh. 
Tabel 2. Rerata ukuran benih Jati putih (Gmelina arborea Roxb) dari beberapa habitat tempat tumbuh

\begin{tabular}{clcc}
\hline No & \multicolumn{1}{c}{ Lokasi Sumber Benih } & \multicolumn{2}{c}{ Ukuran Benih } \\
\cline { 3 - 4 } & & Panjang benih $(\mathrm{mm})$ & Diameter benih $(\mathrm{mm})$ \\
\hline 1 & Kalianda (Lampung Selatan) & 18,32 & 10,25 \\
2 & Bondowoso (Jawa Timur) & 17,78 & 9,64 \\
3 & Bantul (Yogyakarta) & 19,24 & 11,40 \\
4 & Parungpanjang (Bogor, Jawa Barat) & 19,41 & 9,42 \\
5 & Lombok (Nusa Tenggara Barat) & 18,58 & 10,31 \\
\hline
\end{tabular}

Pengamatan terhadap hasil eksplorasi benih Jati putih dari beberapa habitat menunjukkan bahwa rata-rata benih dari habitat Parungpanjang memiliki benih yang terpanjang $(19,41 \mathrm{~mm})$ tetapi diameternya paling pendek $(9,42$ $\mathrm{mm})$, benih dari habitat Bantul memiliki panjang $(19,24 \mathrm{~mm})$ dengan diameternya $(11,24 \mathrm{~mm})$. Ukuran benih Jati putih sangat menentukan pertumbuhan bibit, hal ini seperti dilaporkan Siregar (2010) bahwa ukuran benih berpengaruh nyata terhadap tinggi bibit, diameter batang, panjang akar, berat kering dan ratio tunas dengan akar. Hal ini diduga karena benih ukuran besar mempunyai cadangan makanan yang lebih tinggi dibandingkan dengan benih ukuran kecil, sehingga memberikan keserempakan tumbuh dan kecepatan tumbuh yang lebih baik, sesuai dengan pendapat Soetopo (2005), bahwa semakin besar berat dan ukuran benih maka semakin tinggi cadangan makanan yang tersedia dalam benih.

\section{Kesimpulan}

Hasil kegiatan eksplorasi benih di Kalianda (Lampung Selatan) sebanyak 25 pohon induk, di Bondowoso (Jawa Timur) 30 pohon induk, di Bantul (Yogyakarta) 21 pohon induk, di Parungpanjang (Bogor, Jawa Barat) 15 pohon induk dan Lombok (Nusa Tenggara Barat) 17 pohon induk. Benih Jati putih (Gmelina arborea Roxb.) yang masak fisiologis tiap daerah berpariasi, akan tetapi waktu puncak musim buah antara bulan Oktober sampai bulan Nopember. Ukuran benih Jati putih yang lebih besar memilki keserempakan tumbuh dan kecepatan berkecambah yang lebih baik dibandingkan dengan benih yang berukuran kecil. Keterlibatan masyarakat sangat diperlukan dalam upaya peningkatan kualitas hutan rakyat terutama dalam penyediaan benih bermutu. Selain itu diperlukan suatu upaya perbaikan sitem sertifikasi sumber benih, pengembangan sumber benih dan penguatan kelembagaan pengelolaan sumber benih.

\section{Ucapan Terima Kasih}

Penulis mengucapkan banyak terima kasih kepada Dr. Ir. Mudji Susanto MP. sebagai koordinator penelitian Pemuliaan Jenis Kayu Pertukangan dan team peneliti serta teknisi kayu pertukangan. Penulis juga mengucapkan terima kasih yang tak terhingga kepada Kepala/Staf Dinas Kehutanan setempat (tempat pengambilan benih) yang telah membantu dalam pelaksanaan ekplorasi benih Jati putih di lapangan.

\section{Daftar Pustaka}

Anggraeni , I. \& Mindawati, I. 2011. Serangan Hama dan Penyakit pada Gmelina (Gmelina arborea Roxb) di Hutan Rakyat. Pusat Penelitian dan Pengembangan Peningkatan Produktivitas Hutan Tanaman. Tekno Hutan Tanaman. Vol. 4 No. 2. Hal; 85-92.

Diniyati, D. \& Awang, S.A. 2010. Kebijakan Penentuan Bentuk Insentif Pengembangan Hutan Rakayat di Wilayah Gunung Sawal, Ciamis dengan Metode AHP. Jurnal Analisis Kebijakan Kehutanan. Vol 7. No 2. Hal: 129-143.

Falah, M.D., Supryo, H. \& Hardiwinoto, S. 2005. Pengaruh Cara Penyiapan Lahan, Pupuk Kompos dan Olah Tanah Terhadap Pertumbuhan Gmelina arborea. Seminar Nasional. Peningkatan Produktivitas Hutan. Peran Konservasi Sumber Daya Genetik, Pemuliaan dan Silvikultur Dalam Mendukung Rehabilitas Hutan (Prosiding). Hal : 165- 171.

Hakim, L., Leksono, B., \& Setiadi, D. 2010. Eksplorasi Tengkawang (Shorea spp) di sebaran alam Kalimantan untuk konservasi sumber daya genetik dan populasi pemuliaan. Prosiding Seminar Nasional Mapeki XIII; 
Pengembangan Ilmu dan Teknologi Kayu untuk mendukung Implementasi Program Perubahan Iklim. Mapeki Bali 10-11 Nopember 2010. Hal 813-822.

Haryadi, D. L. Setyaningsih \& Satjapradja, O. 2006. Pengaruh Ukuran Benih Terhadap Perkecambahan Benih Gmelina arborea Asal Kebun Percobaan Cikampek dan Nagrak. Jurnal Nusa Sylva, Fakultas Kehutanan Universitas Nusa Bangsa. Bogor. Vol 6. No. 1. Hal: 10-16.

Lempang, M. \& Tikupadang, H. 2013. Aplikasi Arang Aktif Tempurung Kemiri Sebagai Komponen Media Tumbuh Semai Melina (Gmelina arborea Roxb). Jurnal Penelitian Kehutanan Wallacea. Vol 2. No 2. Hal: 121-137.

Pramono. 2008. Atlas Benih Tanaman Hutan Indonesia. Publikasi Khusus Vol. 2 No. 3.

Pamoengkas, P., Siregar, I.Z., Wijayanto, N., Yulianti., \& Syamsuwida, D. 2012. Pengembangan Sumber Benih Mindi (Melia azedarach) Untuk Hutan Rakyat di Jawa Barat. Jurnal Ilmu Pertanian Indonesia. Vol. 17. No. 1. Hal; 35-40.

Rimbawanto, A., S.D, H. Santoso, N. Masripatin, \& N.P. Priyono. 2008. Pedoman Penyelenggaraan Konservasi Sumber Daya Genetik Tanaman Hutan Tingkat Desa. Puslitbang Hutan Tanaman, BalitbangKehutanan. Bogor.

Statistik Dalam Angka. 2017. Badan Pusat Statistik Kabupaten Bogor, Kecamatan Parungpanjang.

Sumardi., Kurniawan, H., \& Misto. 2015. Karakteristik Pertumbuhan Cendana (Santalum album Linn) Asal Populasi Pulau Sumba. Jurnal Penelitian Kehutanan Wallacea. Vol 4. No 2. Hal: 171-177.

Singh, B and B.P. Bhatt. 2008. Provenance Variation in Pod, Seed, and Seedling Traits of Dalbergia sisso Roxb, Central Himalaya, India. Trop. Agric. Res. and Ext.. 11, 39-44.

Setiadi, D. 2016. Keragaman Pertumbuhan Semai Jati putih (Gmelina arborea Robx) dari Beberapa Sumber Asal Benih di Indonesia. Prosiding Seminar: Biodiversitas Keanekaragaman Hayati Indonesia dan Perannya dalam Menunjang Kemandirian Bangsa. Universitas Airlangga Surabaya. Departemen Biologi Fakultas Sains dan Teknologi (pp. 300-310).

Setiadi, D., \& Hamdan, A.A. 2015. Penyebaran Tanaman dan Karakteristik Benih Jati putih (Gmelina arborea Roxb) di Bondowoso, Jawa Timur. Balai Besar Penelitian Bioteknologi dan Pemuliaan Tanaman Hutan. Wana Benih. Vol. 16 No. 2. Hal; 79-86.

Siregar. N. 2010. Pengaruh ukuran benih terhadap perkecambahan dan pertumbuhan bibit gmelina (Gmelina arborea Roxb). Balai Penelitian Teknologi Perbenihan Bogor. Tekno Hutan Tanaman. Vol. 3 No.1 (1-5).

Schmidt, I. 2000. Pedoman Penanganan Benih Tanaman Hutan Tropis dan Sub Tropis. Danida Forest Seed Centre. Direktorat Jendral Rehabilitasi Lahan dan Perhutanan Sosial. Departemen Kehutanan

Syaffari, K.A., \& Danu. 2013. Manual Budidaya Jati Putih (Gmelina arborea Roxb). Kementrian Kehutanan.

Kerjasama dengan Badan Penelitian dan Pengembangan Kehutanan Pusat Penelitian dan Pengembangan Peningkatan Produktivitas Hutan dengan Direktorat Jendral Bina Pengelolaan Daerah Aliran Sungai dan Perhutanan Sosial Direktorat Bina Perbenihan Tanaman Hutan.

Soetopo, L. 2005. Teknologi Benih. Fakultas Pertanian. Universitas Brawijaya. Jakarta. 